\title{
Biochemical characterization of spiromesifen and spirotetramat as lipid synthesis inhibitors on cotton leaf worm, Spodoptera littoralis
}

\author{
Ragaei M. Abdel-Fatah', Samy M. Mohamed ${ }^{2}$, Atef A. Aly ${ }^{1}$ and Al-Kazafy H. Sabry ${ }^{1 *}$
}

\begin{abstract}
Background: Two lipid synthesis inhibitors compounds (spiromesifen SPM and spirotetramat SPT) were used against the second instar larvae of cotton leaf worm, Spodoptera littoralis under laboratory condition. Toxicity of both compounds was tested. Effect of these insecticides on total lipid also was determined.

Results: The obtained results showed that both compounds were moderately toxic against the second instar larvae of $\mathrm{S}$. littoralis. The mortality percentages caused by the field rate of spiromesifen and spirotetramat were 51.7 and $60.0 \%$, respectively. The lethal concentrations for $50 \%$ of tested insect population $\left(L C_{50}\right)$ were 170.1 and $42.2 \mathrm{ppm}$, respectively. The total lipid content was determined in treated larvae and compared with the untreated. The percentage of total lipid in spiromesifen- and spirotetramat-treated larvae was 2.17 and $2.21 \%$, respectively, compared with $2.42 \%$ in untreated larvae. GC/MS also was used in identification of fatty acids composition of S. littoralis larvae.

Conclusion: The results cleared that 13 fatty acids were identified in S. littoralis larvae. The obtained results showed significant difference in percentages of fatty acids with both treated and untreated larvae and also, between tested compounds. Some fatty acids were existed in untreated larvae but not existed in treated larvae.
\end{abstract}

Keywords: Lipid synthesis inhibitors, Spiromesifen and spirotetramat, Fatty acids

\section{Introduction}

The Egyptian cotton plays an important role in Egyptian society by providing job opportunities and tradable goods to support the economy (Baffes 2005). Egypt's cotton production has been growing for the past few decades and is ranked as one of the best cotton products in the world because of its long fibers which make it strong and soft. The Egyptian cotton is attacked by many insect pest. The cotton leaf worm is considered one of the most destructive pest that attacks the cotton crop (Horowitz et al. 1995). The host rang of this pest is 122 hosts from 44 different plant families (Hatem et al. 2009). The larvae feed on the leaves causing large bores of

\footnotetext{
* Correspondence: kazafyhassan@yahoo.com

${ }^{1}$ Pests and Plant Protection, National Research Centre, Cairo, Egypt Full list of author information is available at the end of the article
}

irregular shape and usually all that remains are the bigger veins. The larvae infest the bud and young boll causing them to be shed or dry up (Bishara 1934). Lipid synthesis inhibitors are insecticides that affect on the cell's ability to synthesize lipids in treated pests. It was known that lipids are important in maintaining the structural integrity of the cell as they are the main component of the cell membrane.

Spiromesifen and spirotetramat are insecticides that belong to a new insecticide class called lipid synthesis inhibitors (Nauen et al. 2006). The mode of action of this class is specific against the immature stages (Nauen et al. 2008). These insecticides reduce the fecundity and fertility of treated insects which lead to reduce the insect populations. Spirotetramat is a systemic insecticide. Nauen et al. (2008) found that the fecundity of adult 
whiteflies and aphids was affected when treated with spirotetramat. Spiromesifen acts as inhibitors of acetyl-coenzyme A carboxylase (ACCase) and causes reduction in total lipid biosynthesis (Nauen 2005). Dangi and Lim (2017) recommended that spirotetramat was suitable in integrated pest management program (IPM) for Riptortus pedestris. This work aims to throw some light on the efficacy of spirotetramat and spiromesifen as lipid synthesis inhibitors on the second instar larvae of Spodoptera littoralis. This work aims also to determine the total lipid and fatty acids in treated larvae.

\section{Methods}

\section{Tested insect}

The second instar larvae of $S$. littoralis were obtained from Pests and Plant Protection Department. The tested larvae were fed on new, fresh, and cleaned castor leaves treated by tested insecticides. Castor leaves were chosen as natural host plants because it is available all the year round and most convenient for larval feeding. Three concentrations were used in each tested insecticides (the field rate concentration and other two concentrations). Each concentration has three replicates and three replicates treated by water as a control. The tested concentrations of spiromesifen were 120, 60, and $30 \mathrm{ppm}$ while spirotetramat was 80,40 , and $20 \mathrm{ppm}$. The castor leaves were cleaned and dried to use in toxicity evaluation. The castor leaves were dipped in tested concentrations and the larvae fed on. All treated larvae were kept under laboratory conditions $\left(25^{\circ} \mathrm{C}\right.$ and $\left.70-75 \mathrm{RH}\right)$. The toxicity of tested insecticides was determined and $\mathrm{LC}_{50}$, for each insecticide calculated by Proban Program Computer Software by using of the insecticide concentration and percent of mortality.

\section{Tested insecticides}

Spiromesifen (Oberon 24\% SC) a lipid synthesis inhibitors. The field rate is $200 \mathrm{ml} / / \mathrm{ha}$.

Spirotetramat (Movento 10\% SC) a lipid synthesis inhibitors. The field rate is $320 \mathrm{ml} / /$ ha.

\section{Biochemical analysis \\ Lipids extraction}

Total lipids content of both treated and untreated larvae were determined using the method described by Folch et al. (1957). Total wet weight of each group of insects (20 larvae per sample) was calculated. Each group was extracted by homogenizing in chloroform: methanol $(2: 1, v: v)$ with assistance of ultrasonic water bath and subsequently purified according to the method of Nicolaysen and Nygaard 1963. The crude extract chloroform/ methanol mixture was washed several times with weak salt solutions of $\mathrm{NaCl}$ (saline solution, $0.85 \% \mathrm{NaCl}$ aqueous solution). The upper phase was discarded and the lower chloroform phase was collected, dried over anhydrous $\mathrm{NaSO}_{4}$, filtering, and evaporated to dryness under reduced pressure; the purified lipids were desiccated over phosphorus pentoxide to a constant weight and total lipid content was calculated gravimetrically as a percentage of wet weight.

\section{Analysis of total lipids \\ Isolation and identification of saponifiable and unsaponifiable matter of lipids extracts}

Total lipid extract (100 mg) was saponified with alcoholic $\mathrm{KOH} \mathrm{10 \%} \mathrm{(ethanol} \mathrm{95 \% )} \mathrm{and} \mathrm{the} \mathrm{residue} \mathrm{was} \mathrm{frac-}$ tionated into unsaponifiable and saponifiable matters according to the method of Farag et al. (1986) as well as the fatty acids were liberated by acidification of the saponifiable matter, extracted with ether, three times, dried over anhydrous $\mathrm{Na}_{2} \mathrm{So}_{4}$, and concentrated under reduced pressure. The percentages of total lipid reduction were calculated according to Abdel-Naby (2017) as follows:

The percentages of lipid reduction

$$
=\frac{\text { Total lipid in control-Total lipid in treatment }}{\text { Total lipid in control }} \times 100
$$

\section{Analysis of total fatty acids}

The fatty acid methyl esters were prepared according to the method adopting by Kinsella (1966). Free fatty acids (about $10 \mathrm{mg}$ ) were refluxed with methanol $(20 \mathrm{ml}, \mathrm{HPLC}$ grade) in the presence of an acidic catalyst $\left(2 \% \mathrm{H}_{2} \mathrm{SO}_{4}\right.$ Analar) for $3 \mathrm{~h}$; after cooling, the fatty acid methyl esters (FAMEs) were extracted from the reaction three times with hexane. The combined hexane layers were neutralized by anhydrous $\mathrm{Na}_{2} \mathrm{CO}_{3}$, dried over anhydrous $\mathrm{Na}_{2} \mathrm{SO}_{4}$, filtered, and concentrated under reduced pressure in a rotary evaporator. Fatty acid methyl esters and unsaponifiable matter were analyzed by GC/MS and were identified on the basis of fragmentation pattern of mass spectra data and a library database [Wiley (Wiley Institute, Los Angeles, CA), NIST (National Institute of Technology, Los Angeles, CA)] and by comparison with previous data. Quantitative determination was carried out on the basis of peak area measurements of the GC/MS chromatograms. GC/MS analysis was carried out in the Central Laboratory of National Research Centre, Egypt.

\section{Gas chromatography-mass spectrometry analysis for FAME}

The gas chromatography-mass spectrometry analysis (GC-MS) system (Agilent Technologies) was equipped with gas chromatograph (7890B) and mass spectrometer detector (5977A) at Central Laboratories Network, National Research Centre, Cairo, Egypt. The GC was equipped with HP-5MS column $(30 \mathrm{~m} \times 0.25 \mathrm{~mm}$ internal diameter and $0.25 \mu \mathrm{m}$ film thickness). Analyses were carried out using 
helium as the carrier gas at a flow rate of $1.0 \mathrm{ml} / \mathrm{min}$ at a split ratio of 1:30, injection volume of $1 \mu \mathrm{l}$, and the following temperature program: $150{ }^{\circ} \mathrm{C}$ for $1 \mathrm{~min}$; rising at $2{ }^{\circ} \mathrm{C} / \mathrm{min}$ to $200{ }^{\circ} \mathrm{C}$ and held for $4 \mathrm{~min}$; rising at $5{ }^{\circ} \mathrm{C} / \mathrm{min}$ to $300{ }^{\circ} \mathrm{C}$ and held for $1 \mathrm{~min}$. The injector and detector were held at $280{ }^{\circ} \mathrm{C}$ and $300{ }^{\circ} \mathrm{C}$, respectively. Mass spectra were obtained by electron ionization (EI) at $70 \mathrm{eV}$ and using a spectral range of $m / z \quad 40-450$ and solvent delay $2 \mathrm{~min}$. Most of the compounds were identified using two different analytical methods: mass spectra (authentic chemicals, Wiley spectral library collection and NSIT library) and by comparison with previous references and data.

\section{Statistical analysis}

Data were subjected to the analysis of variance test (ANOVA) via randomized complete block design (RCBD) ( $F$ test) and analysis of variance (one-way classification ANOVA) followed by a least significant difference (LSD) at 5\% (Costat Statistical Software 1990).

\section{Results}

Toxicity of spiromesifen and spirotetramat to the second instar larvae of $\mathrm{S}$. littoralis

Recommended concentrations and two subrecommended concentrations of both tested insecticides are used against the second instar larvae of S. littoralis (Table 1).

The obtained results show that the recommended concentration of spiromesifen and spirotetramat caused 51.7 and $60.0 \%$ mortality percentage, respectively. The $\mathrm{LC}_{50}$ are 170.1 and $53.7 \mathrm{ppm}$, respectively (Table 1 ). This result cleared that both tested insecticides have moderate toxicity against $S$. littoralis. Malformed larvae treated by s spirotetramat and spiromesifen were observed (Fig. 1). It was known that the lipid is considered one of the most important content in insect cuticle. Using of lipid synthesis inhibitors reduced the total lipid in insect cuticle and cuticle was cut (Fig. 1a, b). The aims of lipid in cuticle is preserving of water in insects cuticle. So, when the total lipids were reduced by tested insecticides, the cuticle was drayed (Fig. 1c).

\section{Biochemical assays \\ Effect of SPM and SPT on the total lipid content of Spodoptera littoralis larvae}

Lipids are important source of energy for insects and are essential structural components of the cell membrane and cuticle. The percentage of total lipid of normal and treated larvae with SPM and SPT were 2.42\%, 2.17\%, and $2.21 \%$, respectively (Table 2 ).

The obtained data recorded that revealed decrease in the level of total lipid per wet weight post treatment with SPM and SPT comparing with normal larvae. The treatment with SPM and SPT resulted in reduction in the total lipid contents by 10.33 and $8.67 \%$. However, lipid content decline could point to a shift in energy metabolism to lipid catabolism due to insecticidal stress. This indicates that lipid content of larvae is more susceptible to insecticide treatment.

GC/MS spectral results and comparison of results with library search successfully enabled the identification of 13 fatty acids. Palmitic saturated fatty acid was detected as major.

(49.64-53.94\%) (Table 3), whereas oleic acid unsaturated one was the second most abundant (30.77-41.9\%) in control and treated larvae lipids. There was significant difference among treatments and control larvae lipids in the percentage of palmitic acid. From the data, it was observed that the percentage of palmitic acid decrease by $13 \%$ in SPM-treated larvae with a concomitant increase by $8.66 \%$ in SPT-treated larvae in comparison with control. Also the data showed the same difference was detected in the percentage of oleic acid in both control and SPM-treated larvae with increase by $36.17 \%$ in SPM-treated larvae more than control, at the same time there was no difference among SPT treatment and control larvae in the percentage of oleic acid.

The same results were observed in the level of linoleic acid in both control and SPM-treated larvae and there was no difference in the percentage of linoleic acid among SPT treatment and control larvae lipids. The percentage of stearic acid was declined by $18 \%$ in SPM-treated larvae in comparison with control one. On the other hand, there was no significant difference among SPT treatment and control larvae lipids in the percentage of stearic acid.

Table 1 Toxicity of spiromesifen and spirotetramat on second instar larvae of cotton leaf worm, S. littoralis

\begin{tabular}{|c|c|c|c|c|c|}
\hline \multirow{2}{*}{$\begin{array}{l}\text { Concentrations } \\
\text { Insecticides }\end{array}$} & \multicolumn{3}{|c|}{ Percent of mortalities } & \multirow{2}{*}{$\begin{array}{l}\text { Slope } \\
\text { values } \pm \text { SE }\end{array}$} & \multirow{2}{*}{$\begin{array}{l}\text { LC50 and } \\
\text { fiducial limits }\end{array}$} \\
\hline & C1 & $C 2$ & $\mathrm{C3}$ & & \\
\hline Spiromesifen & $51.7 \pm 2.9^{a}$ & $38.3 \pm 2.9^{a}$ & $21.7 \pm 2.9^{a}$ & $1.35 \pm 0.3$ & $170.1(81.3-184.1)$ \\
\hline Spirotetramat & $60 \pm 8.7^{\mathrm{a}}$ & $41.7 \pm 2.9^{\mathrm{a}}$ & $28.3 \pm 2.9^{b}$ & $1.39 \pm 0.3$ & 53.7 (42.2-77.3) \\
\hline$F$ values & $2.5^{\mathrm{ns}}$ & $2.2^{\mathrm{ns}}$ & $8.1^{*}$ & - & - \\
\hline LSD & 14.6 & 6.5 & 6.5 & - & - \\
\hline
\end{tabular}

C1: first concentration (recommended field rate), C2: second concentration (1/2 recommended field rate), C3: third concentration (1/4 recommended field rate) Means under each variety sharing the same letter in are not significantly different at $P<0.05$ 

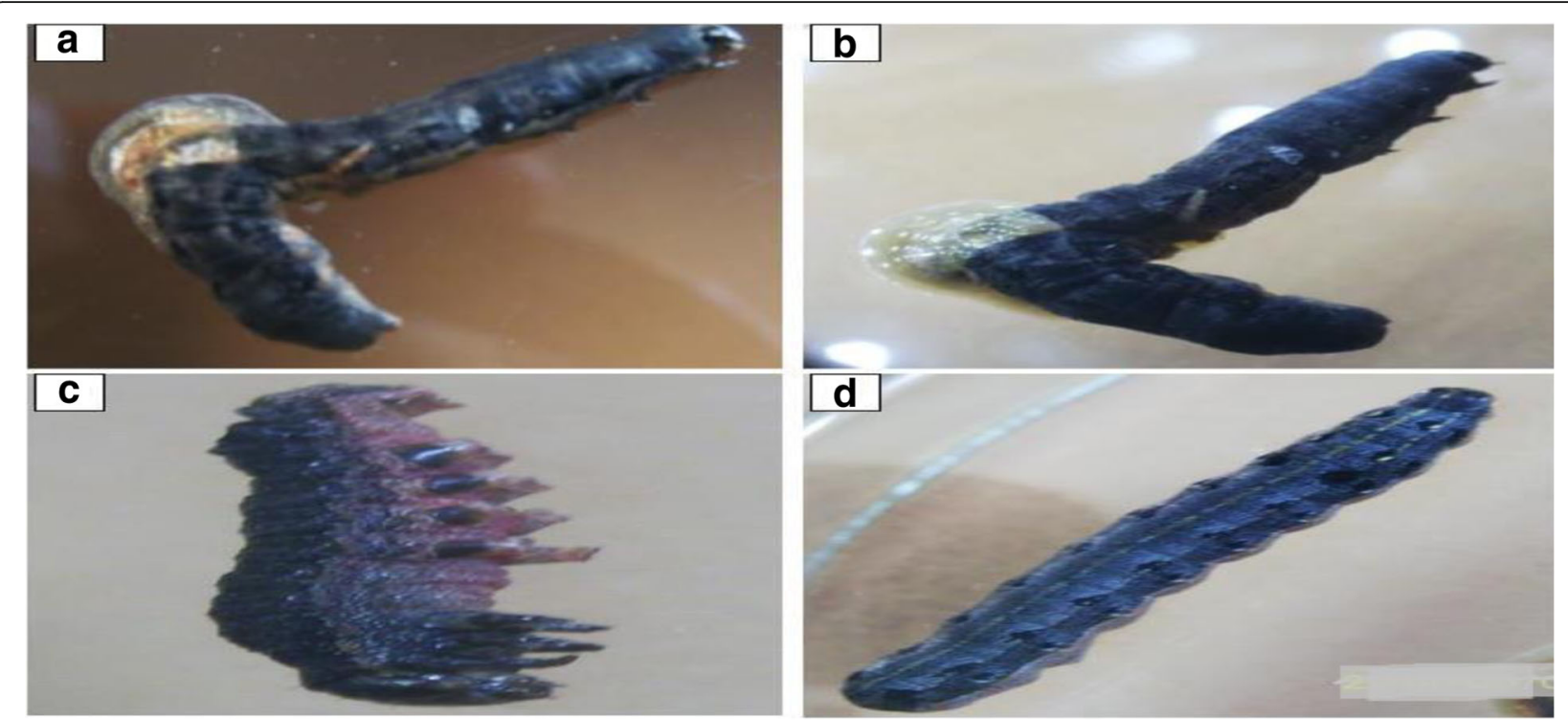

Fig. 1 Malformation caused by spirotetramat $(\mathbf{a}, \mathbf{b})$ and spiromesifen $(\mathbf{c})$ compared to untreated larvae (d)

Myristic, palmitoleic, and heptadecanoic acids were present in minute quantities in the lipids of the control and both treated larvae. There were no great differences in the composition of fatty acids among SPT treatment and control larvae lipids but it was observed important differences between control insect and SPM-treated larvae fatty acids profiles in particular the level of palmitic and oleic acids.

Nonanoic acid, 9-oxo, undecanoic acid, 10-methyl, pentadecanoic, nonadecanoic, arachidic, and behenic acids were quantitatively minor fatty acids were present (Table 3), in control insects which are characteristically absent in both SPM and SPT insects.

Regarding to the percentage of saturated and unsaturated fatty acids, it was observed that the level of saturated fatty acids accounted $64.14 \%$ in control larvae to $52.41 \%$ in SPM-treated larvae, whereas the level of unsaturated fatty acids in control and in SPM-treated larvae were 35.86\% and $47.59 \%$ respectively that may be due to the effects of the insecticide treatment which converted the saturated fatty acid to unsaturated in SPM-treated larvae. Also the data showed that there was no difference detected in the percentage of saturated and unsaturated fatty acids among control and SPT-treated larvae. So, saturation/unsaturation ratio decreased significantly from 1.79 in control insects to

Table 2 The percentages of total lipid in the second instar larvae of S. littoralis treated by spiromesifen and spirotetramat

\begin{tabular}{lll}
\hline Insecticides & $\begin{array}{l}\text { Percentages of } \\
\text { total lipid }\end{array}$ & $\begin{array}{l}\text { Percentages of total } \\
\text { lipid reduction }\end{array}$ \\
\hline Spiromesifen & 2.17 & 10.33 \\
Spirotetramat & 2.21 & 8.67 \\
Control & 2.42 & - \\
\hline
\end{tabular}

1.10 in SPM-treated larvae because of an increase in unsaturation accompanying a decrease in saturation fatty acids in comparison to control. Then the ratio of saturated/unsaturated fatty acids remained almost constant between control insects 1.79 and 1.84 in SPT-treated larvae.

\section{Discussion}

As mentioned in Table 1, the toxicity of both spiromesifen and spirotetramat was moderately against the second instar larvae of S. littoralis. This result was consistent with the result observed by Sabry et al. (2015). The authors found that the toxicity of spirotetramat against Bemisia tabaci and Liriomyza trifolii was 26.9 and 18.4\%, respectively. Kontsedalov et al. (2009) found that the percent of Adult $B$. tabaci mortality was $40 \%$. This result cleared that the main mode of action of these insecticides was not mortality.

The efficacy of these insecticides on total lipid was cleared. They facilitate water conservation both by the formation of an impermeable cuticular barrier and by yielding metabolic water upon oxidation, and they include important hormones and pheromones (Gilbert 1967). It is essential for growth and reproduction and provides energy needed during extended non-feeding periods by storing and releasing energy in response to the energy demands of the insect (Arrese and Soulages 2010). Also the main source of energy for the developing embryo (Beenakkers et al. 1985; Van Handel 1993), and are an important component of insect overwintering energetic Sinclair and Marshall (2018). Lipids are obtained from the diet or are synthesized by the insect itself (Gilby and Gilly 1965) and turnover in insects by neuroendocrine-controlled feedback loops (Downer 1985). 
Table 3 Effect of SPM and SPT on the fatty acids composition of S. littoralis larvae

\begin{tabular}{|c|c|c|c|c|c|c|c|}
\hline Peak & RT & Name & Formula & $\begin{array}{l}\text { Molecular } \\
\text { weight }\end{array}$ & $\begin{array}{l}\text { Relative \% } \\
\text { control }\end{array}$ & $\begin{array}{l}\text { Relative \% } \\
\text { SPM }\end{array}$ & $\begin{array}{l}\text { Relative \% } \\
\text { SPT }\end{array}$ \\
\hline 1 & 3.801 & Nonanoic acid, 9-oxo-, methyl ester & $\mathrm{C}_{10} \mathrm{H}_{18} \mathrm{O}_{3}$ & 186 & 0.75 & 0 & 0 \\
\hline 2 & 4.944 & Undecanoic acid, 10-methyl-, methyl ester & $\mathrm{C}_{13} \mathrm{H}_{26} \mathrm{O}_{2}$ & 214 & 0.15 & 0 & 0 \\
\hline 3 & 9.178 & Tetradecanoic acid, methyl ester)Myristic acid methyl ester ( & $\mathrm{C}_{15} \mathrm{H}_{30} \mathrm{O}_{2}$ & 242 & 1.58 & 0.88 & 0.266 \\
\hline 4 & 12.14 & Pentadecanoic acid, methyl ester & $\mathrm{C}_{16} \mathrm{H}_{32} \mathrm{O}_{2}$ & 256 & 0.58 & 0 & 0 \\
\hline 5 & 14.792 & $\begin{array}{l}\text { 9-Hexadecenoic acid, methyl ester, (Z)-(Palmitoleic acid } \\
\text { methyl ester) }\end{array}$ & $\mathrm{C}_{17} \mathrm{H}_{32} \mathrm{O}_{2}$ & 268 & 1.57 & 0.77 & 1.07 \\
\hline 6 & 15.783 & Hexadecanoic acid, methyl ester(Palmitic acid methyl ester) & $\mathrm{C}_{17} \mathrm{H}_{34} \mathrm{O}_{2}$ & 270 & 49.64 & 43.18 & 53.94 \\
\hline 7 & 19.264 & Heptadecanoic acid, methyl ester & $\mathrm{C}_{18} \mathrm{H}_{36} \mathrm{O}_{2}$ & 284 & 1.08 & 0.65 & 0.95 \\
\hline 8 & 21.83 & $\begin{array}{l}\text { 9,12-Octadecadienoic acid (Z,Z)-, methyl ester (Linoleic acid } \\
\text { methyl ester) }\end{array}$ & $\mathrm{C}_{19} \mathrm{H}_{34} \mathrm{O}_{2}$ & 294 & 3.52 & 4.92 & 3.284 \\
\hline 9 & 22.24 & $\begin{array}{l}\text { 9-Octadecenoic acid (Z)-, methyl ester (Oleic acid methyl } \\
\text { ester) }\end{array}$ & $\mathrm{C}_{19} \mathrm{H}_{36} \mathrm{O}_{2}$ & 296 & 30.77 & 41.9 & 30.77 \\
\hline 10 & 23.207 & Octadecanoic acid, methyl ester (Stearic acid methyl ester) & $\mathrm{C}_{19} \mathrm{H}_{38} \mathrm{O}_{2}$ & 298. & 9.4 & 7.7 & 9.72 \\
\hline 11 & 27.121 & Nonadecanoic acid, methyl ester & $\mathrm{C}_{20} \mathrm{H}_{40} \mathrm{O}_{2}$ & 312 & 0.24 & 0 & 0 \\
\hline 12 & 31.745 & Eianoic acid, methyl ester (Arachidic acid methyl ester) & $\mathrm{C}_{21} \mathrm{H}_{42} \mathrm{O}_{2}$ & 326 & 0.37 & 0 & 0 \\
\hline 13 & 37.698 & Docosanoic acid, methyl ester (Behenic acid methyl ester) & $\mathrm{C}_{23} \mathrm{H}_{46} \mathrm{O}_{2}$ & 354 & 0.35 & 0 & 0 \\
\hline \multicolumn{5}{|c|}{$\%$ of unsaturated fatty acids } & 35.86 & 47.59 & 35.124 \\
\hline \multicolumn{5}{|c|}{$\%$ of saturated fatty acids } & 64.14 & 52.41 & 64.876 \\
\hline \multicolumn{5}{|l|}{ Total } & 100 & 100 & 100 \\
\hline
\end{tabular}

Several studies have shown the interpretation and fluctuation of lipid content in insects treated with different insecticides. Harper et al. (1977) explained that decreasing total lipid under the stress of pesticide reflect on their immediate utilization to meet the energy demands.

Lohar and Wright (1993) observed a reduction in the amount of lipid in haemolymph, fat body, and oocyctes in Tenebrio molitor L. (Coleoptera: Tenebrionidae) females exposed to malathion. They stated that depletion of lipid content might have been due to the effect of insecticide on the adipokinetic hormone that controls lipid metabolism. Regarding the total lipid content, a number of toxic agents have been found to cause disturbances of fats in different body organs of both vertebrate and invertebrate animals (Rawi et al. 1995).

Abdel-Aal (2006) found that chlorfluazuron caused significant decrease of total protein, lipids, and carbohydrates in Spodoptera littoralis larva. The levels of glycogen, protein, and lipid tended to decline with respect to controls in all stages and sexes of the wasp of the endoparasitoid Pimpla turionellae L. (Hymenoptera: Ichneumonidae) reared on Galleria mellonella L. (Lepidoptera: Pyralidae) exposed to various sublethal doses of cypermethrin (Sak et al. 2006). Alimohamadi et al. (2014) reported significant reduction in the amount of lipid in spirodiclofen-treated Hippodamia variegata larvae. Total lipids content showed rise in resistant and decline in susceptible beetles Rhyzopertha dominica, treated by deltamethrin at above sublethal concentrations (Ali et al. 2014). Allethrine insect repellent caused decreased level of lipid content in both the male and female cockroaches. Periplaneta americana (Amrutsagar and Joshi 2017).

\section{Conclusion}

Spiromesifen and spirotetramat were moderately toxic against the second instar larvae of $S$. littoralis. The efficacy of these insecticides was on the fatty acids. Fatty acids serve as precursors in the biosynthesis of pheromones, waxes, and eicosanoids. Moreover, fatty acids are structural components of membranes and defensive secretions (Stanley-Samuelson et al. 1988), and they are essential components in the function of the cuticle (Blomquist and Dillwith 1985). Because the relative importance of these functions varies throughout the development, the rate of fatty acids biosynthesis also would be expected to fluctuate according to physiological needs. Many factors influence the fatty acids composition, such as environmental temperature, stage of development, diet, sex, diapause, and migratory flight (Beenakkers et al., 1985). The results showed that both spirotetramat and spiromesifen can be used in integrated pest management program. The lipid synthesis inhibitors are promising pesticides in insect control. 


\section{Abbreviations}

$L C_{50}$ : Lethal concentration of $50 \%$ of total insect population; SPM: Spiromesifen; SPT: Spirotetramat

\section{Acknowledgements}

Great thanks for all staff member in Pests and Plant Protection Department.

\section{Funding}

This work was personally funded by the authors.

\section{Availability of data and materials}

The datasets used and/or analyzed during the current study are available from the corresponding author on reasonable request.

\section{Authors' contributions}

RM participated in scientific idea and chemical characterization; SM carried out the biochemical characterization assay and participates in writing the paper; AA collected the data and participated in writing the paper; and $\mathrm{AH}$ carried out toxicity assay, collected the data, participated in writing the paper, and publishing the paper. All authors read and approved the final manuscript.

\section{Ethics approval and consent to participate}

Not applicable.

\section{Consent for publication}

Not applicable.

\section{Competing interests}

The authors declare that they have no competing interests.

\section{Publisher's Note}

Springer Nature remains neutral with regard to jurisdictional claims in published maps and institutional affiliations.

\section{Author details}

'Pests and Plant Protection, National Research Centre, Cairo, Egypt.

${ }^{2}$ Department of Medicinal and Aromatic Plants Research, National Research Centre, Cairo, Egypt.

Received: 21 September 2018 Accepted: 1 April 2019

Published online: 18 April 2019

\section{References}

Abdel-Aal AE (2006) Effect of chlorfluazuron, nuclear polyhydrosis virus (SLNPV) and Bacillus thuringiensis on some biological and enzymes activity of cotton leafworm, Spodoptera littoralis (Boisd). Bull Ent Sic Egypt Econ Ser 32:171-185

Abdel-Naby SM (2017) Effect of chlorophyllin compound (Photosensitizer) on main metabolites level of Spodoptera littoralis, total carbohydrates, total proteins, and total lipid. Egypt Acad J Biolog Sci 10(8):53-66

Ali NS, Ali SS, Shakoori AR (2014) Biochemical response of malathion-resistant and -susceptible adults of Rhyzopertha dominica to the sublethal doses of deltamethrin. Pakistan J Zool 46(2):853-861

Alimohamadi N, Samih MA, Izadi H, Shahidi-Noghabid S (2014) Developmental and biochemical effects of hexaflumuron and spirodiclofen on the ladybird beetle, Hippodamia variegata (Goeze) (Coleoptera: Coccinellidae). J Crop Prot 3(3):335-344

Amrutsagar MV, Joshi SS (2017) Insect repellent induced lipid diversions of Periplaneta americana. Int J Rec Sci Res 8(7):18370-18372

Arrese EL, Soulages JL (2010) Insect fat body: energy, metabolism, and regulation. Annu Rev Entomol 55:207-225

Baffes J (2005) The "Cotton problem". World Bank Res Obser 20(1):109-144

Beenakkers AM, Horst D, Marrewilk V (1985) Insect lipids and lipoproteins, and their role in physiological processes. Progr Lipid Res 24:19-67

Bishara I (1934) The cotton worm Prodenia litura F. in Egypt. Bull Soc Entomol d'Egypte 18:223-404

Blomquist GJ, Dillwith JW (1985) Cuticular lipids. 117-154. In: Kerkut GA, Gilbert LI (eds) Comprehensive Insect Physiology, Biochemistry and Pharmacology. Pergamon Press, Oxford

Costat Statistical Software (1990) Microcomputer program analysis Version 4.20. Cohort Software, Berkeley
Dangi N, Lim UT (2017) Relative toxicity of spirotetramat to Riptortus pedestris (Hemiptera: Alydidae) and its egg parasitoids. J Econ Entomol 110(5):2016-2021

Downer RGH (1985) Lipid metabolism. In "Comprehensive insect physiology, biochemistry and pharmacology" Ceds:Kerkut, G.A and Gilbert, L.I, Pbl. Pergamon Press, Oxford 10:75-114

Farag RS, Hallabo SAS, Hewedi FM, Basyony AE (1986) Chemical evaluation of rapeseed. Fette, Seifen, Anstrichmittel 88(10):391-397

Folch JM, Lees M, Stanley GH (1957) A simple method for the isolation and purification of total lipids from animal tissues. J Biol Chem 226:497-509

Gilbert LI (1967) Lipid metabolism and function in insects. Adv Insect Physiol 4:69-211

Gilby Y, Gilby R (1965) Lipids and their metabolism in insects. Anu Rev Ent 10: $141-160$

Harper A, Rodwell WW, Mayes A (1977) Review of physiological chemistry, 16th edn. Lange Medical Pub, California, p 289

Hatem AE, Homam HB, Amer RAM, Abdel-Samad SSM, Saleh HA, Hussien Al (2009) Synergistic activity of several acids in binary mixtures with synthetic insecticides on Spodoptera littoralis (Boisduval). Bol San Veg Pla 35:533-542

Horowitz AR, Forer G, Ishaaya I (1995) Insecticide resistance management as a part ofan IPM strategy in Israeli cotton fields. In: Constable GA, Forrester NW (Eds) Challenging the Future: Proceedings of the World Cotton Research Conference-1. CSIRO, Melbourne, pp 537-544

Kinsella JE (1966) Metabolic patterns of the fatty acids of Periplanteta americana (L.) during its embryonic development. Can J Biochem 44(2):247-258

Kontsedalov S, Gottlieb Y, Ishaaya I, Nauen R, Horowitz R, Ghanim M (2009) Toxicity of spiromesifen to the developmental stages of Bemisia tabaci biotype B. Pest Manag Sci 65(1):5-13

Lohar MK, Wright DJ (1993) Changes in the lipid content in haemolymph, fat body and oocytes of malathion treated Tenebrio molitor L. Adult females. Pak J Zool 25:57-60

Nauen R (2005) Spirodiclofen: mode of action and resistance risk assessment in tetranychid pest mites. Pestic Sci Soc Jap 30:272-274

Nauen R, Bretschneider T, Elbert A, Fischer R, Reckmann U, van Waetermeulen X (2006) Biological and mechanistic considerations on the mode of action of spirotetramat $11^{\text {th }}$ IUPAC Int. Congress of Pesticide Chemistry, Kobe, Japan. Book of Abstracts (2), II-1-i-21C, p.109

Nauen R, Reckmann U, Thomzik J, Thielert W (2008) Biological profile of spirotetramat (Movento ${ }^{\circledR}$ - —a new two-way systemic (Ambimobile) insecticide against sucking pest species. Bayer CropSci J 61 (2):245-278

Nicolaysen R, Nygaard AP (1963) The determination of triglycerides and phospholipids. Stand. J clin Lab Invest 15:79-82

Rawi SM, El-Gindy H, Haggag AM, Abou El Hassan A, Abdel Kader A (1995) Few possible molluscicides from calendula Micrantha officinalis and Ammi majus plants. I. Physiological effect on B. alexandrina and B. truncatus. J Egypt Ger Soc Zool 16:69-75

Sabry KH, Abd-El Rahman TA, Abolmaaty SM (2015) Influence of some new insecticides on sweetpotato whitefly, Bemisia tabaci and American serpentine leafminer, Liriomyza trifolii and their residues in cucumber fruits. Int J Adv Res 3(10):1874-1881

Sak O, Uckan F, Ergin E (2006) Effects of cypermethrin on total body weight, glycogen,protein, and lipid contents of Pimpla turionellae (L.) (Hymenoptera : Ichneumonidae). Belg.J Zool 136(1):53-58

Sinclair BJ, Marshall KE (2018) The many roles of fats in overwintering insects. J Exp Biol 221:jeb161836. https://doi.org/10.1242/jeb.161836

Stanley-Samuelson DW, Jurenka RA, Cripps C, Blomquis GJ, De Renobales M (1988) Fatty acids in insect composition, metabolism, and biological significance. Arch Insect Biochem Physiol 9:1-33

Van Handel E (1993) Fuel metabolism of the mosquito (Culex quinquefasciatus) embryo. J. Insect Physiol 39:831-833 